\title{
RESPON PIHAK SEKOLAH TERHADAP KOMPETENSI MAHASISWA PPL PRODI PGMI STAIN CURUP TA 2014/2015
}

\author{
Oleh: \\ Siti Zulaiha, Ummul Khair * \\ *Dosen Jurusan PGMI STAIN Curup Bengkulu \\ Email:la_lagithu@yahoo.com
}

\begin{abstract}
ABSTRAK
Permasalahan yang dikaji adalah tentang bagaimana respon pihak-pihak sekolah terhadap kemampuan mahasiswa PPL STAIN Curup, yang dilaksanakan pada tanggal 19 Januari s.d. 19 Maret pada tahun 2015. Tujuan penelitian ini untuk mendeskripsikan respon pihak sekolah terhadap kompetensi pedagogik, kompetensi kepribadian, kompetensi sosial, kompetensi profesional mahasiswa PPL dan respon guru pamong terhadap siswa dalam menerima mahasiswa PPL, STAIN Curup di sekolah-sekolah dalam wilayah kabupaten Rejang Lebong.

Penelitian ini merupakan penelitian lapangan (field Research) dengan pendekatan kualitatif dan mengambil lokasi penelitian di SD/MI se-Kota Curup dengan sumber data guru pamong/kepala sekolah. Pengumpulan data dilakukan dengan metode wawancara, dan dokumentasi. Teknik analisis dimulai dengan reduksi data, penyajian data, dan menarik kesimpulan. Analisis data dilakukan sejak penulis di lapangan, sewaktu pengumpulan data, dan setelah semua data terkumpul atau setelah selesai penelitian di lapangan.
\end{abstract}

Keyword: Respon, Kompetensi PPL

\section{A. PENDAHULUAN}

Idealnya setiap tahun haruslah ada peningkatan kualitas Praktik Pengalaman Lapangan( PPL). Praktek Pengalaman Lapangan merupakan salah satu langkah yang dapat ditempuh untuk meningkatkan kualitas lulusan mahasiswa Tarbiyah suatu Perguruan Tinggi. Berkaitan dengan hal itu, maka diperlukan adanya pembinaanpembinaan seperlunya sesuai masalah di lapangan, salah satunya mengenai kemampuan dalam mengelola kelas, yang mencangkup empat aspek kompetensi seorang guru.

Praktik Pengalaman Lapangan memiliki visi untuk mengembangkan kemampuan profesional keguruan. Misalnya adalah untuk pembentukan kemampuan mengajar khususnya mencakup pemahaman karakteristik siswa, kemampuan merancang pembelajaran, kemampuan mengelola kelas, kemampuan mengembangkan media, strategi pembelajaran dan kemampuan mengevaluasi proses dan hasil belajar siswa. 
Dalam dunia pendidikan, keberadaan guru dan fungsi guru merupakan salah satu faktor yang sangat signifikan. Keberadaan guru merupakan bagian yang sangat penting dalam proses belajar mengajar, baik dijalur pendidikan formal maupun pendidikan non formal. Oleh sebab itu, dalam setiap upaya peningkatan kualitas pendidikan tentu tidak akan dapat dilepaskan dari berbagai hal yang berkaitan dengan eksistensi seorang pendidik yaitu guru.

Masalah kualitas guru, saat ini disinyalir sangat memperihatinkan. Berdasarkan data tahun 2002/2003, dari 1,2 juta guru SD kita saat ini, hanya 8,33\% nya yang berijazah sarjana. Realitas semacam ini, pada akhirnya akan mempengaruhi kualitas anak didik yang dihasilkan. Belum lagi masalah, dimana seorang guru sering mengajar lebih dari satu mata pelajaran yang tidak jarang, bukan merupakan corn/ inti dari pegetahuan yang dimilikinya, telah menyebabkan proses belajar mengajar menjadi tidak maksimal. (Daryanto, 2013: 2)

Tuntutan perkuliahan disemua prodi yaitu mengharuskan mahasiswanya memiliki kemampuan yang sesuai dengan bidang yang diambil. Tuntutan itu diterapkan dalam aplikasi kegiatan pendidikan secara langsung di lapangan. Dalam suatu lembaga pendidikan terdapat jenjang-jenjang tertentu yang harus ditempuh untuk menyelesaikan suatu proses pendidikan sebagaimana yang telah ditetapkan oleh lembaga tersebut.

Pada mata kuliah Praktek Pengalaman Lapangan (PPL), mahasiswa "terjun" langsung ke lapangan selama lebih kurang dua bulan. Dengan melakukan program pengalaman lapangan mahasiswa dapat melatih sampai dimana kemampuannya serta menerapkan secara langsung ilmu-ilmu yang pernah didapat selama kuliah di Jurusan Tarbiyah.

Kegiatan PPL memiliki spesifikasi masing-masing disetiap program studi, pendidik yang professional di bidang tertentu. Salah satu langkah yang ditempuh Jurusan Tarbiyah yang profesional adalah dengan menetapkan mata kuliah Program Pengalaman Lapangan (PPL). Melalui Program Pengalaman Lapangan (PPL) ini diharapkan dapat menunjang terciptanya tujuan dari Jurusan Tarbiyah STAIN Curup.

Sesuai dengan tujuan yang diharapkan, Fakultas Tarbiyah menciptakan tenagatenaga pendidik yang profesional dibidang tertentu. Salah satu langkah yang ditempuh Fakultas Tarbiyah yang profesional adalah dengan menetapkan mata kuliah Program Pengalaman Lapangan (PPL). Melalui Program Pengalaman Lapangan (PPL) ini diharapkan dapat menunjang terciptanya tujuan dari Fakultas Tarbiyah tersebut. 
Menurut Hamalik, guru profesional merupakan orang yang telah menempuh program pendidikan guru dan memiliki tingkat master serta telah mendapat ijazah negara dan telah berpengalaman mengajar pada kelas-kelas besar. (Hamalik, 2006 : 27) Hamalik, juga mengatakan bahwa program PPL memiliki sasaran yang harus dicapai, yaitu pribadi calon pendidik yang memiliki seperangkat pengetahuan, keterampilan, nilai dan sikap, serta pola tingkah laku yang diperlukan bagi profesinya serta cakap dan tepat menggunakannya di dalam penyelenggaraan pendidikan dan pengajaran, baik di sekolah maupun di luar sekolah. Pencapaian sasaran tersebut tidak semudah yang diperkirakan, karena pada dasarnya program PPL merupakan tempat menerapkan teori yang sudah diperoleh semasa kuliah. Di sisi lain, kegiatan menerapkan teori tersebut tidak mudah. Banyak permasalahan dan hal terjadi yang awalnya tidak diduga. Awal permasalahan tersebut bisa juga diakibatkan oleh mahasiswa praktikan yang masih belum menguasai materi, salah menerapkan metode mengajar, dan berbagai kasus dalam latihan mengajar. Akibatnya timbul kerusakan pada suasana belajar. Ketika suasana belajar tidak kondusif, yang terjadi adalah tujuan belajar tidak tercapai. Alasan lain pengangkatan permasalahan ini adalah karena sebagian dosen menganggap kompetensi mahasiswa PPL masih sangat kurang.

Berdasarkan Undang-undang Nomor 14 Tahun 2005 tentang guru dan dosen, pada pasal 10 ayat (1) menyatakan bahwa, " Kompetensi guru sebagaimana dimaksud dalam Pasal 8 meliputi kompetensi pedagogik, kompetensi kepribadian, kompetensi sosial, dan kompetensi profesional yang diperoleh melalui pendidikan profesi” (UU Guru \& Dosen : 84)

Standar kompetensi guru mencakup kompetensi inti guru yang dikembangkan menjadi kompetensi guru PAUD, TK/RA, SD/MI, dan matapelajran pada SD/MI, SMP/MTs, SMA/MA, dan SMK/MAK.(Daryanto : 3) Pada hakikatnya, standar kompetensi dan sertifikasi guru adalah untuk mendapatkan guru yang baik dan profesional, yang memiliki kompetensi untuk melaksankan tujuan sekolah khususnya, serta tujuan pendidikan pada umumnya, sesuai kebutuhan masyarakat dan tuntutan zaman. 


\section{B. PEMBAHASAN}

\section{Tinjauan tentang Praktik Pengalaman Lapangan (PPL)}

\section{a. Pengertian Praktik Pengalaman Lapangan}

Praktek Pengalaman Lapangan merupakan salah satu kegiatan intra kurikulum yang dilaksanakan oleh mahasiswa. (Tim PPL, 2014:1) Menurut Oemar Hamalik, Praktik Pengalaman Lapangan adalah, suatu kegiatan intra kurikuler yang dilaksanakan oleh mahasiswa, yang mencangkup baik latihan mengajar maupun tugas-tugas kependidikan, di luar mengajar secara terbimbing dan terpadu untuk memenuhi persyaratan pembentukkan profesi kependidikan. (Hamalik, 2003 :170) Konsep praktik pengalaman lapangan juga berdasarkan pada penyesuaian dengan kemampuan individu, lingkungan sekolah dan masyarakat, kegiatan yang sistematis dan bertahap, penilaian secara kontinue-komulatif, menyeluruh dan bersifat membimbing.

Program pengalaman lapangan pada hakikatnya adalah: (Hamalik, 2003 :92)

1. Dilakukan Seseorang Secara Terbimbing

Dalam melakukan program pengalaman lapangan. Seseorang calon guru dibimbing oleh dosen (supervisor) dan guru pamong yang selalu memberikan bimbingan.

2. Bersifat Latihan yang diperagakan dalam Mengajar

Program pengalaman lapangan yang dijalankan bersifat latihan. Sekalipun sifatnya latihan, namun harus diingat bahwa seseorang yang menjalankan program pengalaman lapangan haruslah benar-benar bersifat dan bersikap sebagai guru.

3. Bertujuan untuk Mendapatkan Keterampilan Mengajar

Dalam program pengalaman lapangan, maka salah satu fungsi dan tujuannya adalah untuk mendapatkan keterampilan dalam mengajar.

4. Salah satu syarat untuk memenuhi suatu program bagi seorang mahasiswa fakultas ilmu kependidikan sebelum mereka menyelesaikan program studinya mereka diwajibkan lebih dahulu menjalankan tugas-tugasnya, yang berkenaan dengan program pengalaman lapangan.

Dapat disimpulkan praktik pengalaman lapangan, merupakan suatu rangkaian tahapan yang harus dilakukan oleh mahasiswa setelah menyelelesaikan sejumlah 
SKS, guna mendapatkan pelajaran yang berupa praktik langsung dalam mengajar disuatu tingkat sekolah. Praktik pembelajaran adalah latihan melaksanakan kegiatan pembelajaran oleh mahasiswa di dalam kelas, mulai dari membuat perencanaan pembelajaran (RPP), pelaksanaan dan penilaian. Sedangkan praktik pengelolaan administrasi adalah latihan melaksanakan tugas-tugas administrasi, bimbingan dan lain-lain. Dalam melaksanakan tugas-tugas PPL ini mahasiswa dipandu oleh pihak sekolah/Madrasah (kepala sekolah/madrasah, waka kurikulum, kepala TU dan guru pamong), dan dibimbing oleh Dosen Pembimbing Lapangan (DPL).

\section{b. Tahap-tahap PPL}

Kegiatan PPL STAIN Curup biasanya dilakukan selama dua bulan, (Tim Panitia, $2014:$ 12) dengan beberapa tahap dalam kegiatan tersebut sebagai berikut:

1) Tahap Orientasi

Tahap orientasi bertujuan untuk memberikan pengetahuan, keterampilan, pengalaman, serta petunjuk-petunjuk praktis tentang pelaksanaan PPL, dengan harapan para mahasiswa memiliki kesiapan dalam menghadapi tugas yang akan mereka hadapi pada pelaksanaan PPL di lokasi sekolah.

2) Tahap Observasi

Pada tahapan observasi mahasiswa PPL, bagi mahasiswa non regular dapat ditempatkan di sekolah tempat mereka mengajar masing-masing, atau bersamaan dengan lokasi PPL mahasiswa kelas regular.

3) Latihan Mengajar

Latihan mengajar di sekolah merupakan tahap yang paling penting dan menetukan dalam keseluruhan pelaksanaan PPL. Semua mahasiswa PPL harus dapat memahami dan melaksanakan tugas-tugas yang berhubungan dengan latihan mengajar.

\section{c. Pengertian Respon}

Respon memiliki beberapa arti, di antaranya: dalam KLBI, respon merupakan kata benda, yang menandakan reaksi, tanggapan, sambutan, jawaban (Zul Fajri, 2008 : 709). Respon yang dimaksud adalah, tentang tanggapan dari responden terhadap subjek, atau sampel penelitian. Respon yang dimaksud merupakan suatu tanggapan yang diberikan oleh pihak sekolah terhadap kemampuan mahasiswa pada awal kegiatan melaksnakan kegiatan PPL sampai berakhirnya 
kegiatan.

Berdasarkan definisi di atas maka respon merupakan suatu pendapat seseorang atau suatu kelompok terhadap suatu aktifitas yang dilakukan yang dilandasi oleh fakta-fakta yang berlagsung dilapangan. Terkhusus lagi terhadap kegiatan yang dilakukan oleh mahasiswa PPL jurusan Tarbiyah, yang mengajar di sekolah-sekolah.

\section{Tinjauan tentang Kompetensi}

\section{a. Pengertian}

Istilah kompetensi guru mempunyai banyak makna, Broke and Stone dalam bukunya E. Mulyasa mengemukakan bahwa kompetensi guru sebagai, ...descriptive of qualitative nature of teacher behavior appears to be entirely meaningful,... kompetensi guru merupakan gambaran kualitatif tentang hakikat perilaku guru yang penuh arti. (Mulyasa, 2009 : 25)

Dalam kamus lengkap bahasa Indonesia (KLBI), kata kompetensi merupakan kata benda yang berarti kewenangan untuk memutuskan sesuatu. (Mulyasa, 2009 : 479) Kompetensi merupakan suatu tingkat kemampuan dan pemahaman yang dapat diukur dengan suatu implementasi.

Lebih lanjut pengertian kompetensi dimaknai sebagai suatu sifat (karakteristik) orang-orang (kompeten) yakni yang memiliki kecakapan, daya (kemampuan), otoritas (kewenangan), kemahiran (keterampilan), pengetahuan, dan sebagainya. (Saud, 2010 : 44) Kompetensi merupakan gambaran hakikat kualitatif dan perilaku seseorang. Menurut Lefrancois, kompetensi merupakan kapasitas untuk melakukan sesuatu, yang dihasilkan dari proses belajar. (Ramayulis, 2013 : 52) Selama proses belajar stimulus akan bergabung dengan isi memori dan menyebabkan terjadinya perubahan kapasitas untuk melakukan sesuatu. Kompetensi diartikan oleh Cowell dalam bukunya Ramayulis, sebagai suatu keterampilan/ kemahiran yang bersifat aktif. (Ramayulis, 2013 : 53) Kompetensi dikategorikan mulai dari tingkat sederhana atau dasar hingga lebih sulit atau kompleks yang pada gilirannya akan berhubungan dengan proses penyusunan bahan atau pengalaman belajar yang lazimnya terdiri dari: (1) penguasaan minimal kompetensi dasar, (2) praktik kompetensi dasar, dan (3) penambahan penyempurnaan atau pengembagan terhadap kompetensi atau 
keterampilan. Ketiga proses tersebut dapat terus berlangsung selama masih ada kesempatan untuk melakukan penyempurnaan atau pengembangan kompetensinya.

Menurut E. Mulyasa dalam bukunya "Kompetensi guru merupakan perpaduan antara kemampuan personal, keilmuan, teknologi, soaial, dan spiritual yang secara kafah membentuk kompetensi standar profei guru, yang mencakup penguasaan materi, pemahaman terhadap peserta didik, pembelajaran yang mendidik, pengembangan pribadi dan profesionalitas". (Mustafah, 2011 : 17)

\section{b. Jenis-jenis Kompetensi Keguruan}

Empat Kompetensi Guru Berdasarkan Undang-Undang :

1) Kompetensi Pedagogik

Kompetensi pedagogik adalah, kemampuan pemahaman terhadap peserta didik, perancanagn dan pelaksanaan pembelajaran, evaluasi hasil belajar, dan pengembangan peserta didik untuk mengaktualisasikan berbagai potensi yang dimilikinya. Sub kompetensi dalam kompetensi Pedagogik (Wiyani, 2015 : 61) adalah:

a) Memahami peserta didik, dengan mememfaatkan prinsip prinsip perkembangan kognitif, prinsip-prinsip kepribadian, dan mengidentifikasi bekal ajar awal peserta didik.

b) Merancang pembelajaran, termasuk memahami landasan pendidikan untuk kepentingan pembelajran, menentukan strategi pembelajaran berdasarkan karakteristik peserta didik, kompetensi yang ingin dicapai, dan materi ajar, serta menyusun rancangan pembelajaran berdasarkan karakteristik peserta didik, kompetensi yang ingin dicapai, dan materi ajar, serta menyusun rancangan pembelajaran berdasarkan strategi yang dipilih.

c) Melaksanakan pembelajaran yang meliputi menata latar (setting) pembelajaran dan malaksanakan pembelajaran yang kondusif.

d) Melaksanakan pembelajaran yang meliputi menata latar (setting) pembelajaran dan melaksanakan pembelajaran yang kondusif.

e) Merancang dan melaksanakan evaluasi pembelajaran yang meliputi merancang dan melaksanakan evaluasi (assessment) proses dan hasil belajar secara berkesinambungan dengan berbagai metode, menganalisis 
hasil evaluasi dan hasil belajar untuk menentukan tingkat ketuntasan belajar (mastery level), dan memamfaatkan hasil penilaian pembelajaran untuk perbaikan kualitas program pembelajaran secara umum.

f) Mengembangkan peserta didik untuk mengaktualisasikan berbagai potensinya meliputi memfasilitasi peserta didik untuk pengembangan berbagai potensi akademik, dan memfasilitasi peserta didik untuk mengembangkan berbagai potensi non-akademik.

2) Kompetensi Kepribadian.

Kompetensi kepribadian adalah kemampuan personal yang mencerminkan kepribadian yang mantap, stabil, dewasa arif dan berwibawa, menjadi teladan bagi peserta didik, dan berakhlak mulia. Sub kompetensi dalam kompetensi kepribadian meliputi:

a) Keperibadian yang mantap dan stabil meliputi bertindak sesuai dengan norma sosial, bangga menjadi guru, dan memiliki konsistensi dalam bertindak sesuai dengan norma.

b) Kepribadian yang dewasa yaitu menampilkan kemandirian dalam bertindak sebagai pendidik dan memiliki etos kerja sebagai guru.

c) Kepribadian yang arif adalah menampilkan tindakan yang didasarkan pada kemamfaatan peserta didik, sekolah dan masyarakat dan menunjukkan keterbukaan dalam berfikir dan bertindak.

d) Kepribadian yang berwibawa meliputi memiliki prilaku yang berpengaruh positif terhadap peserta didik dan memiliki prilaku yang disegani.

e) Berakhlak mulia dan dapat menjadi teladan meliputi bertindak sesuai dengan norma religius ( imtak, jujur, ikhlas, suka menolong) dan memiliki prilaku yang diteladani peserta didik.

3) Kompetensi Profesional

Kompetensi profesional adalah penguasaan materi pembelajaran secara luas dan mendalam, yang mencakup penguasaan materi kurikulum mata pelajaran di sekolah dan substansi keilmuan yang menaungi materinya, serta penguasaan terhadap struktur dan substansi keilmuan yang menaungi materinya, serta penguasaan terhadap struktur dan metodologi keilmuannya yang meliputi: 
a) Menguasai, materi, struktur, konsep, dan pola pikir keilmuan yang mendukung pelajaran yang diampu.

b) Menguasai standar kompetensi dan kompetensi dasar mata pelajaran/ bidang pengembangan yang diampu.

c) Mengembangkan materi pembelajaran yang diampu secara kreatif.

d) Mengembangkan kepropesionalan secara berkelanjutan dengan melakukan tindakan reflektif.

e) Memamfaatkan TIK untuk berkomunikasi dan mengembangkan diri.

\section{4) Kompetensi Sosial}

Kompetensi sosial adalah kemampuan guru untuk berkomunikasi dan bergaul secara efektif dengan peserta didik, tenaga kependidikan, orang tua/ wali peserta didik, dan masyarakat sekitar, diantaranya:

a) Bersikap inklusif, bertindak objektif, serta tidak diskriminatif karena pertimbangan jenis kelamin, kondisi fisik, latar belakang keluarga, dan situasi sosial keluarga.

b) Berkomunikasi secara efektif, empatik, dan santun dengan sesama pendidik, tenaga kependidikan, orang tua dan masyarakat.

c) Beradaptasi di tempat bertugas di seluruh wilayah RI yang memiliki keragaman sosial budaya.

\section{c. Keterampilan Mengajar}

Faktor penting yang akan mempengaruhi keberhasilan pembelajaran adalah kemampuan guru dalam mengelola pembelajaran dari awal sampai akhir pembelajaran:

1) Keterampilan bertanya adalah keterampilan guru mengajukan pertanyaan kepada siswa.

2) Keterampilan memberikan pengguatan, merupakan respon terhadap suatu tingkah laku yang dapat memberikan kemungkinan berulangnya kembali tingkah laku tersebut.

3) Keterampilan mengadakan variasi, penggantian atau perubahan yang terkait dengan satu atau beberapa aspek dalam kegiatan belajar.

4) Keterampilan menjelaskan, bentuk kegiatan dalam menyampaikan informasi 
atau materi pelajaran dalam urutan yang sistematis.

5) Keterampilan membuka dan menutup pelajaran, membuka merupakan kegiatan untuk menciptakan suasana dalam menpersiapkan mental.

6) Keterampilan dalam membimbing diskusi kelompok kecil, dalam suatu kegiatan memungkinkan siswa belajar dalam kelompok kecil.

7) Keterampilan mengelola kelas, keterampilan dalam menciptakan dan mempertahankan kondisi yang optimal.

8) Keterampilan kelompok kecil dan perorangan, kegiatan kelompok seperti tersebut dapat terjadi dalam konteks pengajaran klasikal. (Tim FKIP, 2014 : 32)

Penelitian ini menggunakan penelitian kualitatif berdasarkan teori metode penelitian kualitatis sebagai berikut.Penelitian ini merupakan penelitian lapangan ( field research) yang bersifat deskriptif kualitatif. Dalam penelitian ini penulis mencari dan menggunakan data-data yang bersifat deskriptif yaitu berupa kata-kata atau ungkapan, pendapat-pendapat dari subyek penelitian, baik itu kata-kata secara lisan ataupun tulisan. Pendekatan ini diarahkan pada latar belakang dan individu tersebut secara holistik. (Moleong, $2000: 3$ )

Penelitian ini merupakan penelitian kualitatif yaitu penelitian yang ditujukan untuk memahami fenomena sosial didasarkan pada kondisi obyek yang alamiah, sesuatu yang dinamis, hasil konstruksi, pemikiran dan utuh yakni mempunyai satu kesatuan yang tidak dapat dipisahkan.

Kajian dalam penelitian kualitatif bersifat naturalistik, (Sugiono, 2008 : 295) dinamis, dan holistik karena dalam proses penelitian terdapat interaksi antara penulis dengan subyek penelitian dengan kondisi apa adanya sehingga data yang diperoleh merupakan fenomena yang asli. Penggunaan metode kualitatif dalam penelitian ini adalah untuk mendapatkan data yang lebih lengkap, mendalam, kredibel, dan bermakna sehingga tujuan penelitian dapat dicapai.

Adapun tempat penelitian pada beberapa SD/MI se-Kota Curup yang meliputi: (kota Curup, Kec. Curup Timur, Curup Selatan, Curup Utara, Curup Tengah) . Adapun waktu penelitian akan dilaksanakan dari bulan Juni s.d. Agustus tahun ajaran 2015/2016. Untuk menentukan sumber data pada penelitian ini digunakan teknik purposive dimana penentuan sumber data dengan pertimbangan 
tertentu. Pertimbangan tertentu ini, misalnya orang yang dianggap paling tahu tentang apa yang kita harapkan, atau mungkin dia sebagai penguasa sehingga akan memudahkan peneliti menjelajahi obyek atau situasi sosial yang diteliti. Adapun metode pengumpulan data penelitian ini sebagai berikut :

1. Interview /wawancara

Metode interview dalam penelitian ini digunakan sebagai metode pengumpulan data utama, hal ini dikarenakan peneliti beranggapan bahwa apa yang dikatakan oleh subyek dalam penelitian ini adalah benar dan dapat dipercaya serta peneliti meyakini bahwa interpretasi subyek tentang pertanyaan-pertanyaan yang diajukan peneliti kepadanya adalah sama dengan apa yang dimaksudkan oleh peneliti. (Sutrisno : 194) Selain kedua hal tersebut subyek atau dalam penelitian ini yang dimaksud adalah para guru pamong pada masing-masing sekolah telah melakukan proses evaluasi ketika mahasiswa PPL melaksanakan praktik, sehingga data yang diperoleh bukan berdasarkan perkiraan saja.

2. Metode dokumentasi

Merupakan suatu metode untuk mencari data variabel yang berupa catatancatatan penting, transkip, buku, prasasti dan lain sebagainya. Metode ini digunakan penulis sebagai sarana untuk memperoleh data tentang dokumentasi kegiatankegiatan PPL yang telah dilaksanakan pada masing-masing sekolah yang menjadi objek penelitian. Dokumentasi yang digunakan oleh peneliti adalah: Instrumen lembaran pertanyaan wawancara, foto saat wawancara dengan narasumber.

Mengingat penelitian ini merupakan penelitian kualitatif, maka analisis data dimulai dari lapangan dengan menggunakan metode deskriptif analitik yaitu menyusun dengan cara mendiskripsikan, menafsirkan data dan menganalisa semua hal yang menjadi fokus dalam penelitian. Adapun logika berpikir yang digunakan yaitu logika berpikir induktif.

Adapun analisis data kualitatif dalam penelitian ini menggunakan analisis yang dikembangkan oleh Miles dan Huberman, dimana penulis menganalisis data dimulai dengan menelaah seluruh data yang tersedia dari berbagai sumber, yaitu wawancara, observasi dan dokumentasi. 


\section{Deskripsi Data Penelitian di Sekolah Wilayah Curup}

Dari hasil pelaksanaan wawancara di sekolah SD Center Curup, dengan narasumber Zakaria S.Pd, MM, peneliti mendapatkan data/ hasil sebagai berikut:

a. Kompetensi Pedagogik.

1) Pada indikator memahami karakter peserta didik. Mahasiswa PPL belum begitu mampu mengayomi, memberikan perhatian, memberikan arahan terhadap dunia belajar sambil bermain sebagaimana dunianya anak-anak.

2) Pada indikator penerapan berbagai pendekatan strategi, metode dan teknik pembelajaran. Mahasiswa PPL sebahagian sudah mampu menerapkan starategi, metode yang menyenangkan, dengan menerapkan metode bermaian berkelompok di dalam kelas.

3) Pada indikator prinsip-prinsip perancangan pembelajaran yang mendidik. Mahasiswa dapat membimbing siswa belajar dengan pendekatan individu, dan kelompok..

4) Pada indikator melakukan evaluasi proses dan hasil belajar. Mahasiswa PPL sudah dapat melakukan penilaian dengan skor penilaian skor masing-masing soal.

5) Pada indikator mengkomunikasikan hasil belajar. Mahasiswa PPL sudah dapat melaporkan hasil belajar dan bertanya kepada guru pamong, tentang skor penilain dan hasil akhir penilaian hasil belajar siswa, tentang ketepannya.

b. Kompetensi Kepribadian

1) Pada indikator menghargai peserta didik. Mahasiswa PPL sudah mampu menerapkannya dan tidak membedakan siswa, dapat dilihat kedekatan komunikasi siswa dengan mahasiswa, seperti bercerita saat jam istirahat siswa menghampiri guru PPLnya untuk berkomunikasi.

2) Pada indikator berprilaku yang dapat diteladani oleh anak didik. Mahasiswa PPL sudah menerapkan prilaku baik seperti cara mereka bersapa tegur dengan baik dan wajar terhadap semua dewan guru dan siswa di sekolah.

3) Pada indikator etos kerja yang bertanggungjawab. Mahasiswa PPL sudah memiliki sikap disiplin yang baik, hadir disekolah tepat waktu, beraktivitas disekolah tanpa selalu diingatkan. Masuk dan keluar kelas seuai dengan waktu jam pelajaran. 
4) Pada indikator menerapkan kode etik guru. Mahasiswa PPL sudah mampu menerapkannya, yaitu berkepribadian dan bersikap sebagaiman mestinya.

c. Kompetensi Sosial

1) Pada indikator kemampuan berkomunikasi dengan teman sejawat dan komunitas yang berada di sekolah. Mahasiswa PPL sudah mampu menerapkannya dengan baik, dan sesama mahasiswa dapat dilihat kebersamaan.

2) Pada indikator melaksanakan berbagai program untuk meningkatkan kualitas pendidikan. Mahasiswa PPL mampu berperan aktif dalam kegiatan ekstrakurikuler dan kegiatan pramuka yang dilaksanakan di sekolah.

d. Kompetensi Profesional

1) Pada indikator membuat perangkat pembelajaran. Mahasiswa PPL selalu menyiapkan sebelum masuk kelas untuk mengajar, perangkat pembelajaran yang dibuat sudah sesuai dengan sistematika yang diharuskan oleh pemerintah.

2) Pada indikator menguasai materi stuktur dan konsep keilmuan terhadap mata pelajaran. Mahasiswa secara umum sudah dapat menerapknnya karena sudah ada tutunan dalam buku paket pembelajaran.

3) Pada indikator kemampuan memberikan contoh materi sesuai kemajuan zaman. Mahasiswa PPL sudah mampu menghubungkan dan memberikan contoh pembelajaran sesuai perkembangan zaman, seperti alat transportasi, dan bentuk kemanjuan dunia saat ini.

4) Pada indikator menerapkan delapan keterampilan mengajar. Mahasiswa PPL sudah mampu menerapkannya, diawali dengan salam, doa, absensi, apersepsi, kemudian masuk pada inti pembelajaran dan penutup suatu pertemuan pembelajaran dengan salam.

\section{Deskripsi Data Penelitian di Sekolah Wilayah Curup Tengah}

Dari hasil pelaksanaan wawancara di sekolah SD Negeri 06 Kec. Curup Tengah dengan narasumber Sumarni Sumai S.Pd, peneliti mendapatkan data/ hasil sebagai berikut:

a. Kompetensi Pedagogik.

1) Pada indikator penerapan berbagai pendekatan strategi, metode dan teknik pembelajaran. Mahasiswa PPL masih harus diingatkan jika mau mengajar. 
2) Pada indikator prinsip-prinsip perancangan pembelajaran yang mendidik. Mahasiswa PPL mengajar sambil mendekati siswa ketempat duduk sambil membimbing agar siswa memahami pelajaran.

3) Pada indikator melakukan evaluasi proses dan hasil belajar. Mahasiswa PPL mampu melaksanan penilaian dengan bimbingan guru pamong.

4) Pada indikator mengkomunikasikan hasil belajar. Mahasiswa PPL menerapkan penilaian dan menkomunikasikannya dengan guru pamong.

b. Kompetensi Kepribadian

1) Pada indikator menghargai peserta didik. Mahasiswa PPL, sudah mampu menghargai peserta didik

2) Pada indikator berprilaku yang dapat diteladani anak didik. Mahasiswa PPL, sudah menerapkannya dengan berbicara secara baik kepada siswa, seperti dalam menegur kesalahan siswa.

3) Pada indikator menunjukkan etos kerja yang bertanggungjawab. Mahasiswa PPL, sudah menerapkannya dengan masuk dan keluar kelas sesuai jadual dan durasi waktu.

4) Pada indikator menerapkan kode etik guru. Mahasiswa PPL, sudah menerapkannya seperti berpakaian pantas.

c. Kompetensi Sosial

1) Pada indikator kemampuan berkomunikasi dengan teman sejawat dan komunitas yang berada di sekolah. Mahasiswa PPL dapat bergaul dengan baik.

2) Pada indikator melaksanakan berbagai program untuk meningkatkan kualitas pendidikan. Mahasiswa PPL, belum mampu tetapi mampu membantu kegiatan pramuka, dan senam pagi Jumat di sekolah

d. Kompetensi Profesional

1) Pada indikator membuat perangkat pembelajaran. Mahasiswa PPL, sudah mampu membuat dan memahaminya.

2) Pada indikator menguasai materi stuktur dan konsep keilmuan terhadap mata pelajaran. Mahasiswa PPL belum sepenuhnya menguasai materi pelajaran yang akan diajarkan di depan kelas. Penguasaan materi ini dapat dilihat waktu 
mahasiswa memberikan contoh sudut kepada mahasiswa hanya memberikan contoh sudut ruangan kelas, maka hal ini tidak dapat dipahami siswa SD.

3) Pada indikator kemampuan memberikan contoh materi sesuai kenyataan dan kemajuan zaman. Mahasiswa PPL, sebahagian materi bisa ia contohkan.

4) Pada indikator menerapkan delapan keterampilan mengajar. Mahasiswa PPL belum sepenuhnya, terkadang mahasiwa langsung menjelakan materi tanpa mengikuti tahap-tahap yang harus dilakukan sebelum mengajar. Seperti tidak melakukan apersepsi.

\section{Deskripsi Data Penelitian di Sekolah Wilayah Curup Timur}

Dari hasil pelaksanaan wawancara di sekolah MIM 14 Talang Ulu Kec. Curup Timur, narasumber Nursa'ada, S.Pd, peneliti mendapatkan data/ hasil sebagai berikut:

a. Kompetensi Pedagogik.

1) Pada indikator memahami karakter peserta didik. Mahasiswa PPL cukup dekat dan mengerti dengan karakter siswa yang beragam, dan berusaha sabar.

2) Pada indikator penerapan berbagai pendekatan strategi, metode dan teknik pembelajaran. Mahasiswa PPL sudah diterapkan dalam mengajar.

3) Pada indikator prinsip-prinsip perancangan pembelajaran yang mendidik. Mahasiswa PPL ada yang sudah mampu menerapkan dan mahasiswa cukup kreatif membuat siswa aktif dalam belajar.

4) Pada indikator melakukan evaluasi proses dan hasil belajar. Mahasiswa PPL sudah mampu mengadakan evaluasi.

5) Pada indikator mengkomunikasikan hasil penilaian belajar. Mahasiswa PPL, sudah melakukannya.

b. Kompetensi Kepribadian

1) Pada indikator menghargai peserta didik. Mahasiswa PPL mampu menerapkannya walau beragam cara siswa.

2) Pada indikator berprilaku yang baik. Mahasiswa PPL, cukup bisa bergaul dengan sesama di sekolah.

3) Pada indikator menunjukkan etos kerja yang bertanggungjawab. Mahasiswa PPL, cukup bertanggungjawab dengan pekerjaan masing-masing. 
4) Pada indikator menerapkan kode etik guru. Mahasiswa PPL cukup menyesuaikan prilaku sopan.

c. Kompetensi Sosial

1) Pada indikator kemampuan berkomunikasi dengan teman sejawat dan komunitas yang berada di sekolah. Mahasiswa PPL cukup baik dalam berkomunikasi antar sesama guru dan siswa.

2) Pada indikator melaksanakan berbagai program untuk meningkatkan kualitas pendidikan. Mahasiswa PPL, melatih siswa menari dan bernyanyi kasidah untuk suatu perlombaan.

d. Kompetensi Profesional

1) Pada indikator membuat perangkat pembelajaran. Mahasiswa PPL, memang diharuskan menyiapkannya sebelum masuk kelas untuk mengajar

2) Pada indikator menguasai materi stuktur dan konsep keilmuan terhadap mata pelajaran. Mahasiswa PPL sebagian mereka mampu menguasai materi, namun masih ada yang belum punya rasa percaya diri dalam mengajar.

3) Pada indikator kemampuan memberikan contoh materi sesuai kemajuan zaman. Mahasiswa PPL sebahagian sudah mampu menyesuaikan contoh nyata.

4) Pada indikator menerapkan delapan keterampilan mengajar. Mahasiswa PPL terkadang masih ada yang lupa dan buru-buru menempel media ajar di papan tulis.

\section{Deskripsi Data Penelitian di Sekolah Wilayah Curup Utara}

Dari hasil pelaksanaan wawancara di sekolah MIN 01 Dusun Curup Kec. Curup Utara, narasumber Sri Wahyuni Sihombing, S.Pd, peneliti mendapatkan data/ hasil sebagai berikut:

a. Kompetensi Pedagogik.

1) Pada indikator memahami karakter peserta didik. Mahasiswa PPL belum dapat mengatasi ributnya siswa dalam belajar.

2) Pada indikator penerapan berbagai pendekatan strategi, metode dan teknik pembelajaran. Mahasiswa PPL, belum begitu memahami strategi dan dalam penerapannya masih belum diawasi dengan baik. 
3) Pada indikator prinsip-prinsip perancangan pembelajaran yang mendidik. Mahasiswa PPL belum begitu mampu menerapkannya karena mahasiswa masih menghafal terhadap materi pelajaran.

4) Pada indikator melakukan evaluasi proses dan hasil belajar. Mahasiswa PPL belum sesuai dalam memberikan penilaian dan skor belum tepat sesuai kesulitan soal yang diujikan.

5) Pada indikator mengkomunikasikan hasil belajar. Mahasiswa PPL sebahagian mereka sudah mengkomunikasikan dan melaksanakan langkah berikut yaitu remedial terhadap hasil belajar siswa.

b. Kompetensi Kepribadian

1) Pada indikator menghargai peserta didik. Mahasiswa PPL cukup baik terhadap siswa dan menghargai siswa serta dekat dalam pergaulan dengan siswa.

2) Pada indikator berprilaku yang dapat diteladani. Mahasiswa PPL sudah dapat menerapkan prilaku sopan, tetapi dalam berpakaian terkadang tidak sesuai dengan yang seharusnya.

3) Pada indikator menunjukkan etos kerja yang bertanggungjawab. Mahasiswa PPL sudah baik dan melaksanakan pembelajaran sccara tepat waktu dan baik.

4) Pada indikator menerapkan kode etik guru. Mahasiswa PPL dapat menyesuaikan diri.

c. Kompetensi Sosial

1) Pada indikator kemampuan berkomunikasi dengan teman sejawat dan komunitas yang berada di sekolah. Mahasiswa PPL sudah mampu bergaul dan sapa tegur yang baik.

2) Pada indikator melaksanakan berbagai program untuk meningkatkan kualitas pendidikan. Mahasiswa PPL belum punya program, masih sebatas membantu kegiatan pramuka.

d. Kompetensi Profesional

1) Pada indikator membuat perangkat pembelajaran. Mahasiswa PPL, sudah mampu membuat perangkat pelajaran. 
2) Pada indikator menguasai materi stuktur dan konsep keilmuan terhadap mata pelajaran. Mahasiswa PPL, terkadang mampu diterapkan secara terstrukur terkadang langsung memberikan materi kepada siswa.

3) Pada indikator kemampuan memberikan contoh materi sesuai kemajuan zaman. Mahasiswa PPL adayang sudah diterapkan tetapi masih ada sebatas buku paket sekolah.

4) Pada indikator menerapkan delapan keterampilan mengajar. Mahasiswa PPL, belum selalu menerapkannya.

\section{Deskripsi Data Penelitian di Sekolah Wilayah Curup Selatan}

Dari hasil pelaksanaan wawancara di sekolah SDN 09 Curup Selatan Curup Selatan dengan narasumber Sri Rahayu, S.Pd., M.T.Pd., peneliti mendapatkan data/ hasil sebagai berikut:

a. Kompetensi Pedagogik.

1) Pada indikator memahami karakter peserta didik.Mahasiswa PPL cukup baik memahami karakteristik peserta didik tingkat SD

2) Pada indikator penerapan berbagai pendekatan strategi, metode dan teknik pembelajaran. Mahasiswa PPL Menerapkan berbagai pendekatan strategi, metode dan teknik pembelajaran yang mendidik yang kreatif, implementasinya seperti menerapkan kerja kelompok, bermain peran, tanya jawab dsb.

3) Pada indikator prinsip-prinsip perancangan pembelajaran yang mendidik. Mahasiswa PPL cukup memahami prinsip-prinsip perancangan pembelajaran yang mendidik di SD

4) Pada indikator melakukan evaluasi proses dan hasil belajar.Mahasiswa PPL dapat melakukan evaluasi proses berupa pengamatan pembelajaran dan hasil belajar baik tes lisan maupun tertulis

5) Pada indikator mengkomunikasikan hasil belajar. Mahasiswa PPL dapat mengkomunikasikan hasil penilaian untuk meningkatkan kualitas pembelajaran, terhadap guru pamong/siswa dengan mengadakan remedial dan pengayaan. 
b. Kompetensi Kepribadian

1) Pada indikator menghargai peserta didik.. Mahasiswa PPL menghargai anak didik tanpa membedakan laki-laki dan perempuan, kaya dan miskin, siswa kurang dan pintar dan lain-lain

2) Pada indikator berprilaku yang baik.Mahasiswa PPL dapat diteladani oleh peserta didik misalnya berpakaian rapi, berbicara dengan sopan

3) Pada indikator etos kerja yang bertanggungjawab.Mahasiswa PPL menunjukkan etos kerja bertanggungjawab yang tinggi diimplementasikan dengan datang tepat waktu

4) Pada indikator menerapkan kode etik guru.Mahasiswa PPL berperilaku sesuai kode etik guru, diimplementasikan dengan menunjukkan sikap dan perilaku yang sopan

\section{c. Kompetensi Sosial}

1) Pada indikator kemampuan berkomunikasi dengan teman sejawat dan komunitas yang berada di sekolah. Mahasiswa PPL mampu berkomunikasi dengan teman sejawat/guru setempat dan komunikasi ilmiah lainnya secara santun, empatik dan efektif

2) Pada indikator melaksanakan berbagai program untuk meningkatkan kualitas pendidikan. Mahasiswa PPL melaksanakan berbagai program/kegiatan untuk meningkatkan kualitas pendidikan dengan melaksanakan program perbaikan dan pengayaan

d. Kompetensi Profesional

1) Pada indikator membuat perangkat pembelajaran. Mahasiswa PPL mampu membuat perangkat pembelajaran, silabus, RPP, LKS dan lain-lain

2) Pada indikator menguasai materi stuktur dan konsep keilmuan terhadap mata pelajaran. Mahasiswa PPL menguasai materi struktur, konsep dan pola pikir keilmuan terhadap mata pelajaran yang diajarkan

3) Pada indikator kemampuan memberikan contoh materi sesuai kemajuan zaman.Mahasiswa PPL mampu memberikan contoh materi pelajaran secara nyata kepada siswa, mengikuti perkembangan zaman, seperti mengaitkan pelajaran dengan kehidupan sehari-hari dan pengalaman nyata dengan lingkungan 
4) Pada indikator menerapkan delapan keterampilan mengajar.Mahasiswa PPL memahami dan menerapkan delapan keterampilan dasar dalam mengajar, mendidik, membimbing, mengarahkan, melatih, menilai, mengevaluasi, melaksanakan program perbaikan dan pengayaan peserta didik

\section{HASIL PENELITIAN}

1. Respon pihak sekolah terhadap kompetensi pedagogik mahasiswa PPL angkatan XVIII (PGMI) tahun 2015.

Jika dilihat dari hasil wawancara di atas atau pada hasil penelitian dan berdasarkan analisis peneliti, respon pihak sekolah cukup baik terhadap kompetensi yang dimiliki oleh para praktikan atau mahasiswa PPL khususnya pada prodi PGMI angkatan XVIII tahun 2015. Dalam hal ini berkaitan dengan kompetensi pedagogik yang merupakan kemampuan pemahaman terhadap peserta didik, perancangan dan pelaksanaan pembelajaran, evaluasi hasil belajar.

Respon sekolah khususnya para guru pamong jika berdasarkan hasil wawancara untuk setiap indikator kompetensi pedagogik cukup baik seperti pada pemahaman terhadap peserta didik, mahasiswa praktikan sudah bisa memahami karakteristik siswa walaupun belum sepenuhnya bisa melakukan analisis yang mendalam atau mengenal lebih jauh, hal ini menurut pendapat peneliti karena waktu yang begitu singkat yakni hanya dalam waktu dua bulan pelaksanaan PPL belum bisa memberikan kesempatan mahasiswa praktikan, selain itu mereka dituntut untuk langsung melaksanakan pembelajaran di kelas. Sehingga para guru pamong beranggapan atau berpendapat praktikan belum bisa maksimal dalam hal pemahaman terhadap karakteristik siswa yang akan diajarnya. Namun respon sekolah secara keseluruhan cukup baik.

2. Respon pihak sekolah terhadap kompetensi kepribadian mahasiswa PPL angkatan XVIII (PGMI) tahun 2015.

Kompetensi kepribadian merupakan kemampuan personal yang mencerminkan kepribadian yang mantap, stabil, dewasa arif dan berwibawa, menjadi teladan bagi peserta didik, dan berakhlak mulia. Berdasarkan hasil wawancara dengan para guru pamong pada setiap indikatornya sudah baik 
pelaksanaannya seperti pada indikator menghargai peserta didik. Mahasiswa PPL sudah mampu menerapkannya dan tidak membedakan siswa laki-laki dan perempuan, kaya atau miskin,kurang dan pintar, hal ini dapat dilihat kedekatan komunikasi siswa dengan mahasiswa, seperti bercerita saat jam istirahat siswa menghampiri guru PPLnya untuk berkomunikasi.

\section{Respon pihak sekolah terhadap kompetensi sosial mahasiswa PPL angkatan XVIII (PGMI) tahun 2015}

Kompetensi sosial yang merupakan kemampuan guru untuk berkomunikasi dan bergaul secara efektif dengan peserta didik, tenaga kependidikan, orang tua/ wali peserta didik, dan masyarakat sekitar. Mahasiswa PPL berkomunikasi dengan baik pada guru dan teman sejawat maupun siswa dengan sikap yang empatik, santun dan efektif. Sedangkan dalam melaksanakan program sekolah walaupun sifatnya membantu mahasiswa PPL telah melaksanakan berbagai program/kegiatan untuk meningkatkan kualitas pendidikan, implementasinya yaitu mahasiswa mau berpartisipasi untuk melakukan penilaian pada siswa yaitu perbaikan dan pengayaan, membantu kegiatan ekstrakurikuler seperti pramuka, mengajar tambahan baca tulis bagi siswa yang belum bisa, dan lain sebagainya.

\section{Respon pihak sekolah terhadap kompetensi profesional mahasiswa PPL angkatan XVIII (PGMI) tahun 2015}

Kompetensi profesional merupakan penguasaan materi pembelajaran secara luas dan mendalam, yang mencakup penguasaan materi kurikulum mata pelajaran di sekolah dan substansi keilmuan yang menaungi materinya, serta penguasaan terhadap struktur dan substansi keilmuan yang menaungi materinya, serta penguasaan terhadap struktur dan metodologi keilmuannya. Menurut para guru pamong sebagai mana pada hasil wawancara untuk kompetensi profesional sudah cukup baik terutama pada indikator membuat perangkat pembelajaran, mahasiswa PPL mampu membuat perangkat pembelajaran, silabus, RPP, LKS dan lain-lain, walaupun masih ada yang membuat setelah kegiatan pembelajaran. 


\section{SIMPULAN}

Hasil penelitian menunjukkan bahwa : 1. Respon pihak sekolah terhadap kompetensi pedagogik mahasiswa PPL angkatan XVIII (PGMI) tahun 2015 baik, mahasiswa praktikan sudah mampu melaksanakan analisis karakteristik siswa, membuat perencanaan pembelajaran telah menggunakan metode, strategi yang bervariasi, melakukan evaluasi dan mengkomunikasikan dengan guru pamong. 2. Respon pihak sekolah terhadap kompetensi kepribadian mahasiswa baik, mahasiswa praktikan tidak membeda-bedakan siswa-siswi baik dari status sosial, ekonomi maupun dari kemampuan dan lain sebagainya. Mahasiswa menunjukkan sikap teladan bagi seorang guru, punya etos kerja yang tinggi dan tanggungjawab, mahasiswa sudah mulai membiasakan diri untuk bersikap sesuai dengan kode etik guru.3. Respon pihak sekolah terhadap kompetensi sosial mahasiswa baik, mahasiswa praktikan mampu berkomunikasi secara baik atau bisa dikatakan berjalan efektif baik terhadap teman sejawat, para guru, dan siswa tentunya. Ikut serta dalam pelaksanaan program sekolah, walaupun sifatnya masih pada tahap membantu. 4. Respon pihak sekolah terhadap kompetensi profesional mahasiswa baik, mahasiswa praktikan telah membuat dan menyusun perencanaan pembelajaran , memahami atau menguasai materi sesuai keilmuan mata pelajaran yang diajarkan walaupun belum fokus seperti guru yang sesungguhnya, mampu memberikan contohcontoh yang kontekstual atau sesuai dengan kehidupan sehari-hari serta sesuai perkembangan zaman walaupun kadang masih belum begitu tepat contoh yang diberikan tetapi sudah mendekati, demikian halnya dengan keterampilan mengajar, mahasiswa praktikan telah menerapkan walaupun masih kesulitan dalam hal pengelolaan kelas.

\section{DAFTAR PUSTAKA}

Daryanto, Standar Kompetensi dan Penilaian Kinerja Guru Profesional Yogjakarta : Gava Media. 2013.

E. Mulyasa, Standar Kompetensi dan Sertifikasi Guru Bandung: PT. Rosdakarya, 2009. Em Zul Fajri \& Ratu Aprilia Senja, Kamus Lengkap Bahasa Indonesia (KLBI), Difa Publisher, 2008. 
Jejen Mustafah, Peningkatan Kompetensi Guru ( Melalui Pelatihan dan Sumber Belajar Teori dan Praktik) Jakarta. Kencana Prenada Media group, 2011.

Lexy J. Moloeng, Metodologi Penelitian Kualitatif, Bandung : PT Remaja Rosdakarya, 2000.

Mardalis, Metode Penelitian Suatu ;Pendekatan Proposal, Jakarta : Bumi Aksara, 1995.

Novan Ardi Wiyani, Etika Profesi Keguruan Yogyakarta : Gava Media, 2015.

Oemar Hamalik, Pendidikan Guru Berdasarkan Pendekatan Kompetensi, Jakarta: Bumi Aksara, 2006.

, Kurikulum dan Pembelajaran Jakarta: Bumi Aksara. 2013

Panitia Pelaksana PPL, Buku Pedoman Praktik Pengalaman Lapangan, Curup, STAIN Curup, 2014.

Ramayulis, Profesi dan Etika Keguruan Jakarta: Kalam Mulia, 2013

Syaiful Bahri Djamarah, Strategi Belajar Mengajar Jakarta: Rineka Cipta, 2010.

Suharsimi Arikunto, Prosedur Penelitian Suatu Pendekatan Praktik Jakarta: PT. Asdi Mahasatya. 2006.

Sutrisno Hadi, Metodologi Research, Yogyakarta : Andi, 2004.

Sugiono, Metode Penelitian Pendidikan : Pendekatan Kuantitatif, Kualitatif, dan R\&D, Bandung : Alfabeta, 2008.

Sardiman, Interaksi dan Motivasi Belajar-Mengajar. Jakarta: Rajawali Pers. 2012

Tim-FKIP UT. Pemantapan Kemampuan Mengajar (PKM-PGSD). Penerbit Universitas Terbuka.2014.

Udin Syaefudin Saud, Pengembangan Profesi Guru, Bandung : Alfabeta, 2010

Zainal Asril. Micro Teaching: Disertai dengan Pedoman Pengalaman Lapanagn. Jakarat: Eajawali Pres. 2013.

Undang-undang Republik Indonesia Nomor 14 Tahun 2005 tentang Guru dan Dosen Jogyakarta, 2006.

Utomo, Kompetensi Mahasiswa Program Studi Bahasa, Sastra Indonesia dan Daerah FKIP Unib Peserta PPL di SMU 6 Kodya Bengkulu Tahun 1999 dalam

http://ejournal.unikama.ac.id/index.php/jrnspirasi/article/view/483, diakses pada tanggal 20 April 2015

http://digilib.fkip.uns.ac.id/contents/skripsi.php?id_skr=1730 
